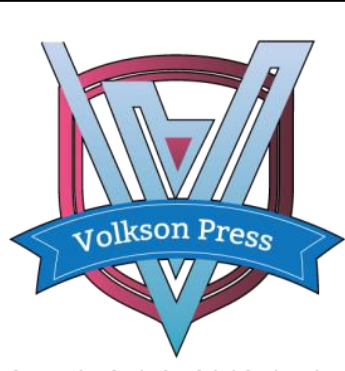

Contents List available at VOLKSON PRESS

Economics \& Management Innovations(EMI)

DOI : http://doi.org/10.26480/icemi.02.2018.33.37

ISBN: 978-1-948012-14-0

\title{
MANAGERIAL OVERCONFIDENCE, INTERNAL CONTROLS AND CORPORATE EFFECTIVE TAX RATE
}

\author{
Zhang Shu-Hui, Chen Ke-Ying*, Wang Rui-Wen \\ International Business School of Shaanxi Normal University, Xi'an, China. \\ *Corresponding Author Email: chen_keying@qq.com
}

This is an open access article distributed under the Creative Commons Attribution License, which permits unrestricted use, distribution, and reproduction in any medium, provided the original work is properly cited.

\section{ARTICLE DETAILS}

\section{Article History:}

Received 26 June 2018 Accepted 2 July 2018

Available online 1 August 2018

\section{ABSTRACT}

In this paper, we make use of the panel data of 2010-2015 Chinese listed companies from Shanghai and Shenzhen A-share markets to explore the impact of managerial overconfidence on the corporate effective tax rate. We identify that overconfident managers are inclined to pursue more authoritativeness and controlling force, so they need to establish the very correct perception through signal expression in accounting behavior-conducting more earnings management activities to display the performance in advance, which makes the effective tax rate increased. Further analyzation shows that a good internal control environment could inhibit the overconfident behavior and assess the group contributions more faithfully, so that the costs of signal expression increased, and the effective tax rate finally decreased. All these results suggest that internal control can exert positive influence on managers behaviors and enhance the corporate value.

\section{KEYWORDS}

Managerial Overconfidence, Internal Controls, Corporate Effective Tax Rate.

\section{INTRODUCTION}

Taxation is one of the most important factors affecting the value of the company. All scales of corporate's financial managers are expected to reduce their tax burden through tax planning. At the same time, as the main source of China's fiscal revenue, under the same tax law system, there is a significant difference in the actual tax burden between the same nominally taxed companies, and the academic community has conducted a large number of studies trying to explore the root causes of this difference.

The existing research on the factors that affect the actual taxation of enterprises can be divided into two aspects: internal and external. From the external view, taxation is the main source of state finance, and taxation of enterprises is fundamentally regulated by the the tax law. At the same time, as a lot of many scholars have proved it may also be interfered by such factors as regional policies, regional tax competition, local government officials works as well as corporate property rights. While the external influence factors of the actual tax burden of the company are gradually clear, domestic and foreign scholars have begun to shift from the external to the internal level of the enterprise to further study and analyze the impact of the actual tax burden. In addition to the universally recognized intrinsic factors, such as company size, capital structure, and industry characteristics. Recently, a number of scholars had found that companies are not passively using and accepting the tax incentives that the country has already introduced, but also actively seeking to reduce the actual taxation of the institutional arrangements, through different ways such as using personal influence to mobilize human and material resources, construct the internal market or the way of group operation. A group researchers proposed that the factors influencing the company's tax burden include not only the characteristics of the company, but also individual executives play an important role in the level of corporate tax avoidance [1]. It means that senior management can also play a key role in organizing tax burdens.
A large and growing numbers of evidence confirmed that most corporate executives have demonstrated overconfidence in their decisions and have influenced the company's investment and financing policies, dividend distribution policies, and compensation structure [2,3]. Overconfidence managers often holding "better than average" beliefs, tend to give higher weight to the information they possess, and are too optimistic about selfability and judgment, often neglecting personally received or observed negative feedback $[1,4]$.

This overconfidence impact on management behavior and further impact on corporate performance is the focus of current research. Short-term overconfidence managers tend to implement positive earnings management to increase profits, while long-term overconfident managers tend to negative profit management to smooth profits. Due to the selfinterest of managers, managers are most likely to guide corporate policy toward self-interest. So, can over-confident managers influence the corporate tax burden intentionally or unintentionally? On the basis of previous studies, this article takes a sample of listed companies in China as an example to empirically test this issue.

\section{THEORETICAL ANALYSIS AND HYPOTHESIS PROPOSED}

\subsection{Managerial Overconfidence and Corporate Effective Tax Rate}

According to the above literature review, it is not difficult to find that corporate manager is a "high-risk group" of "overconfidence" mentality. They often overestimate the accuracy of their own decisions and judgments and the probability of their occurrence. Psychologist pointed out on the issue of how to correctly understand managers' overconfidence [5]. The nature of overconfidence stems from the difference in attention distribution. Overconfident people tend to allocate their attention to relative ease. The result of being motivated and away from the relatively difficult aspects is that they will continue to hold the overconfidence belief that they can perform well at work. Therefore, this paper regards 
overconfidence as an embedded individual cognitive bias, which can guide individuals to exhibit a specific behavioral pattern.

That is, overconfidence managers are optimistic about the future earnings of the company, as well as internal information and the company itself. The ability to carry out higher assessments, for this reason, out of the pursuit of leadership authority and control, they choose to use signal expressions to establish their own very correct ideas, and the accounting behavior will be shown through more earnings management behavior. Come to show performance (profit) in advance, which will increase the actual tax burden of the company. As overconfidence managers tend to ignore effective feedback for improvement, surplus forecast bias persists [6,7]. Based on the above analysis, here we proposed the hypothesis 1: H1: The Managerial Overconfidence is positively related to the corporate effective tax rate. The higher the degree of overconfidence of the management, the higher the actual tax burden of the company.

\subsection{Managerial Overconfidence, Internal Controls and Corporate Effective Tax Rate}

In the above section, earnings management is used as a hub to sort out the possible relationship between over-confidence of managers and the actual tax burden of enterprises. Hypothesis 1 is proposed. On the other hand, corporate earnings management activities and executives' behavior are all subject to internal control mechanisms. High-quality internal controls can effectively suppress accounting choices in earnings management and real activity earnings management. A group researchers pointed out that improving corporate internal governance and information disclosure levels can inhibit managers' overconfidence [8]. In light of the above findings, we believe that good internal controls can constrain managers' overconfidence behavior, so that the cost of achieving control through the expression of profit signals is greatly increased, managerial earnings management behavior is inhibited, and collective evaluation can be more correctly evaluated. Based on this analysis, hypothesis 2: H2: Internal controls can significantly reduce the correlation between management overconfidence and actual corporate tax burden.

\section{RESEARCH DESIGN}

\subsection{Data Sources and Sample Selection}

This article selects A-share listed companies on the Shanghai and Shenzhen Stock Exchanges from 2010 to 2015 as the initial research sample, and excludes ST, PT listed companies, listed companies in the financial and insurance industry, listed companies with missing financial data, and listed companies with CEO changes during the year. The winsorize tailing process was performed on the $1 \%$ and $99 \%$ quintiles of the main continuous variable to eliminate the effects of extreme values.

\subsection{Variable Definition and Design}

As a psychological cognitive trait, overconfidence is a key to the empirical part of this article. Integrating previous studies, balancing the advantages and disadvantages of various measurement methods, and the availability of data, this article uses management shareholding changes and corporate earnings forecast bias as management variables for management overconfidence, respectively. According to portfolio theory, corporate management has reason to hold multiple stocks to reduce risk, if the management of a company increases holdings of the company's stocks in the same year and does not use equity incentives, share offerings, rights issues, etc., it is considered to be a sample of overconfidence. In addition, overconfidence management often overestimates the company's profitability and exceeds actual performance forecasts. Therefore, we take the sample of listed companies that have issued losses, renewal, slight increase, and pre-increase of optimistic performance forecast in all three quarters as overconfident samples. If there is a large positive difference between the performance of the forecast and its actual performance, then the management team is deemed excessive confident management. Based on research and empirical research in the China background, we assumed that the higher the company's management's salary is relative to the average employee, the more important it is in the company's position and the more likely to create managers overconfidence [9]. The details of other variable's definitions are shown in Table 1.

Table 1: Variable Definition

\begin{tabular}{|c|c|c|}
\hline Variable Name & $\begin{array}{l}\text { Variable } \\
\text { Symbol }\end{array}$ & Variable Definition \\
\hline \multirow{3}{*}{$\begin{array}{l}\text { Corporate } \\
\text { Effective } \\
\text { Tax Rate }\end{array}$} & ETR1 & $\begin{array}{l}\text { Income tax expense / Pre-tax } \\
\text { Profits }\end{array}$ \\
\hline & $\begin{array}{l}\text { ETR2 } \\
\text { (Substitution } \\
\text { variable) }\end{array}$ & $\begin{array}{llll}\text { Income } & \text { tax } & \text { expense / } & \text { (Pre-tax } \\
\text { Profits } & - & \text { Net } & \text { non-operating } \\
\text { income) } & & \end{array}$ \\
\hline & $\begin{array}{l}\text { ETR3 } \\
\text { (Substitution } \\
\text { variable) }\end{array}$ & $\begin{array}{l}\text { (Income tax expense - Deferred } \\
\text { income tax expense ) / Pre-tax } \\
\text { Profits }\end{array}$ \\
\hline \multirow{3}{*}{$\begin{array}{l}\text { Managerial } \\
\text { Overconfidence }\end{array}$} & Overcon1 & $\begin{array}{l}\text { Management's increase in } \\
\text { shareholdings, if the company's } \\
\text { management increases holdings of } \\
\text { the company's stocks in the year, } \\
\text { and is not due to equity incentives, } \\
\text { share offerings, rights issues, etc., } \\
\text { it is considered overconfidence } \\
\text { sample with OverCon1 = 1, } \\
\text { otherwise, OverCon1 = } 0\end{array}$ \\
\hline & Overcon2 & $\begin{array}{l}\text { Earnings Discrepancies in the } \\
\text { company's earnings: if the } \\
\text { company fails to achieve the net } \\
\text { profit disclosed in its third quarter } \\
\text { earnings forecast at the end of the } \\
\text { year, it will be regarded as an } \\
\text { overconfidence sample with } \\
\text { OverCon2 = } 1 \text {; otherwise, } \\
\text { OverCon2 }=0\end{array}$ \\
\hline & Overcon3 & $\begin{array}{l}\text { The proportion of management } \\
\text { remuneration is expressed as 'the } \\
\text { sum of the top three highest paid } \\
\text { executive compensation and total } \\
\text { management remuneration' }\end{array}$ \\
\hline Company Size & Size & $\begin{array}{l}\text { Total company assets take natural } \\
\text { logarithms }\end{array}$ \\
\hline Ultimate Owner & Controller & $\begin{array}{l}\text { If the ultimate controller is state- } \\
\text { owned,then } \\
\text { Controller }=1 \text {,otherwise } 0\end{array}$ \\
\hline $\begin{array}{l}\text { Financial } \\
\text { Leverage }\end{array}$ & LEV & The end of the asset - liability ratio \\
\hline $\begin{array}{l}\text { Return on Total } \\
\text { Assets }\end{array}$ & ROA & $\begin{array}{lcc}\text { (Total Profits }+ & \text { Interest } \\
\text { Exchange)/Total Assets } & \end{array}$ \\
\hline $\begin{array}{l}\text { Dispersion of } \\
\text { stock }\end{array}$ & Inventory & Inventory / Total Assets \\
\hline Internal Control & ICI & $\begin{array}{l}\text { The natural logarithm of the } \\
\text { internal control evaluation index }\end{array}$ \\
\hline $\begin{array}{ll}\text { Gross } & \text { Profit } \\
\text { Margin } & \\
\end{array}$ & Grossmargin & $\begin{array}{l}\text { ( Net sales revenue - cost of } \\
\text { production) / Net sales revenue; }\end{array}$ \\
\hline $\begin{array}{l}\text { Ownership } \\
\text { Concentration }\end{array}$ & FS & $\begin{array}{l}\text { The company's largest } \\
\text { shareholder's shareholding }\end{array}$ \\
\hline $\begin{array}{l}\text { Proportion of } \\
\text { intangible } \\
\text { assets }\end{array}$ & Intangible & Intangible Assets/Total Assets \\
\hline YEAR & Year-dummy & $\begin{array}{l}\text { Dummy Variable : If the sample } \\
\text { belongs to a particular year this } \\
\text { variable is } 1 \text {, and } 0 \text { otherwise. }\end{array}$ \\
\hline INDUSTRY & Ind-dummy & $\begin{array}{l}\text { Dummy Variable : If the sample } \\
\text { belongs to a particular industry } \\
\text { this variable is } 1 \text {, and } 0 \text { otherwise. }\end{array}$ \\
\hline
\end{tabular}

\section{3 $\quad$ Model}

We constructed the following model (1) to verify the hypothesis (1): $E_{T R}, t=\alpha_{0}+\alpha_{1}$ Overcon $_{i, t}+\alpha_{2}$ Size $_{i, t}+\alpha_{3}$ Controller $_{i, t}+\alpha_{4} L E V_{i, t}+\alpha_{5} R O A_{i, t}+\alpha_{6}$ Inventor $y_{i, t}+\alpha_{7}$ Grossmargin $_{i, t}+\alpha_{8} F S_{i, t}+\alpha_{9}$ Intangible + Year-dummy + Ind-dummy $+\varepsilon$ (1) And then we constructed the following model (2) to verify the 
hypothesis (2):

ETRi $t=\alpha 0+\alpha 1$ Overconi,$t+\alpha 2$ Overconi $, t^{*} I C I i, t+\alpha 3$ ICIi, $t+\alpha 4$ Sizei,$t+\alpha 5$ Controll

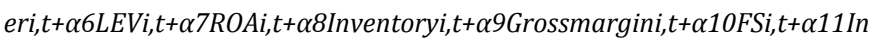

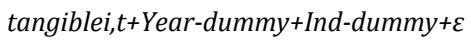

(2)

\section{ANALYSIS OF EMPIRICAL RESULTS}

\subsection{Descriptive Statistics and Correlation Analysis}

Table 2: Descriptive Statistics

\begin{tabular}{|l|l|l|l|l|l|}
\hline Variable & $\begin{array}{l}\text { Sample } \\
\text { Observed }\end{array}$ & Mean & $\begin{array}{l}\text { Standard } \\
\text { deviation }\end{array}$ & Minimum & Maximum \\
\hline ETR1 & 8579 & 0.205 & 0.133 & 0.000 & 0.904 \\
\hline Overcon1 & 8579 & 0.215 & 0.411 & 0.000 & 1.000 \\
\hline Overcon2 & 3307 & 0.102 & 0.303 & 0.000 & 1.000 \\
\hline Size & 8579 & 21.993 & 1.265 & 18.964 & 25.782 \\
\hline Controller & 8579 & 0.470 & 0.499 & 0.000 & 1.000 \\
\hline LEV & 8579 & 0.433 & 0.212 & 0.030 & 0.975 \\
\hline ROA & 8579 & 2.010 & 3.492 & -5.636 & 17.161 \\
\hline Inventory & 8579 & 0.180 & 0.166 & 0.000 & 0.774 \\
\hline ICI & 6294 & 6.540 & 0.115 & 6.033 & 6.839 \\
\hline Grossmargin & 8579 & 27.615 & 16.117 & 0.086 & 78.277 \\
\hline FS & 8579 & 37.608 & 15.552 & 9.086 & 75.996 \\
\hline Intangible & 8579 & 0.048 & 0.057 & 0.000 & 0.369 \\
\hline
\end{tabular}

Table 2 is showing that there is indeed a large difference in the actual tax burden level between different companies. The average value of Overcon1 is 0.215 , which indicates that about $21 \%$ of the management has increased their shareholdings in the company's stock, they're showing overconfidence; the average value of Overcon 2 was 0.102 . This indicates that of all the companies that reported earnings announcements in the third quarter, about $10 \%$ of the companies did not achieve the net profit in the pre-notice, then this $10 \%$ of the company's management is likely to show the characteristics of overconfidence.

In the correlation analysis of the main variables, the two surrogate variables (Overcon1, Overcon2) of management overconfidence are significantly positively correlated with the ETR1 variable reflecting the actual tax burden of the company at the level of $1 \%$. This confirms Hypothesis 1 of this paper. There is a significant positive correlation between Overcon 1 and Overcon2, indicating that the two methods for measuring overconfidence in this paper have a good consistency.

The actual tax burden (ETR1) and company size (Size), the ultimate controller property (Controller), company financial leverage (Lev), return on total assets (ROA), inventory intensity (Inventory) is significantly positively correlated at the $1 \%$ level, and is significantly negatively correlated with Gross Margin at the $1 \%$ level. In addition, the correlation coefficients between the respective variables are less than 0.4 , indicating that there is no autocorrelation between explanatory variables and will not have a serious impact on the results of multiple regression analysis.

\subsection{Regression Analysis and Robustness Analysis}

Shown as the multivariate regression results of model (1) in the left part of Table 3, after controlling for other related factors, the coefficient of overcon 1 is significantly positive at the level of $1 \%$ in the multivariate regression in which management changes in holdings are used as substitution variables of overconfidence. The coefficient of Overcon2 is also significantly positive at the level of $1 \%$ in the regression of performance forecast bias as a substitute for overconfidence. This is consistent with the results of the previous analysis of correlations, which further validates Hypothesis 1.

We further introduced the internal control quality as an influencing factor to test the hypothesis2. From the results in the right part of Table4, it can be seen that when the management shareholding change is used as the Overcon1 surrogate for overconfidence, the coefficient is significantly positive at the $1 \%$ level, and the ICI coefficient is significantly negative at the $1 \%$ level. The coefficient of Overcon $1 *$ ICI is significantly negative at the $1 \%$ level [10]. This shows that internal control relieves the positive correlation between management overconfidence and the actual tax burden of the company. Hypothesis 2 has been verified. The overcon $2 *$ ICI coefficient is also significantly negative. Therefore, the internal control quality has an impact on over-confidence of the management and the actual tax burden of the enterprise.

In the robustness analysis we use management salary ratio as a substitute for management overconfidence to perform robustness tests (see as Table 5). For the availability of data, we use Overcon3, which is the sum of the top three executives with the highest pay and total manager remuneration, to express the degree of overconfidence of management. Two commonly used actual tax burden definitions ETR2 and ETR3 are used to replace the measurement method of actual tax liabilities (see Table1). Using Overcon3 as an independent variable and ETR2 and ETR3 as dependent variables, we re-analyzed the model (1) and model (2) separately. From the results of regression analysis in Table 4, we can see that Hypothesis 1 and Hypothesis 2 are still verified, and the above findings have not changed substantially. Therefore, the conclusion of this study is more robust. 
Topics in Economics, Business and Management (EBM) 2(2) (2018) 33-37

Table 3: Robustness Analysis

\begin{tabular}{|c|c|c|c|c|}
\hline Variable & ETR2 & ETR3 & ETR2 & ETR3 \\
\hline Model & \multicolumn{2}{|l|}{ Model (1) } & \multicolumn{2}{|l|}{ Model (2) } \\
\hline \multirow{2}{*}{ Overcon 3} & $0.0291^{* * *}$ & $0.0267^{* * *}$ & $0.234^{* *}$ & $0.0761^{* * *}$ \\
\hline & $(5.94)$ & $(5.9)$ & $(2.04)$ & (3.96) \\
\hline \multirow{2}{*}{ Overcon3* ICI } & & & $-0.0308^{* *}$ & $-0.00337^{* *}$ \\
\hline & & & $(-2.89)$ & $(-2.56)$ \\
\hline \multirow{2}{*}{ ICI } & & & $-0.0807^{* * *}$ & $-0.0926^{*}$ \\
\hline & & & $(-6.09)$ & $(-1.73)$ \\
\hline \multirow{2}{*}{ Size } & $0.00317^{* * *}$ & $0.00321^{* * *}$ & 0.000389 & 0.00293 \\
\hline & $(5.67)$ & $(5.6)$ & $(0.67)$ & $(0.52)$ \\
\hline \multirow{2}{*}{ Controller } & $0.0352^{* * *}$ & $0.0171^{* * *}$ & $0.0267^{* * *}$ & $0.0218^{* *}$ \\
\hline & $(27.71)$ & (14.11) & (25.08) & (2.08) \\
\hline \multirow{2}{*}{ LEV } & $0.106^{* * *}$ & $0.119^{* * *}$ & $0.0921^{* * *}$ & $0.0577^{*}$ \\
\hline & $(30.43)$ & (36.09) & (30.73) & (1.94) \\
\hline \multirow{2}{*}{ ROA } & $0.00108^{* * *}$ & $-0.00411^{* * *}$ & $0.00219^{* * *}$ & 0.00153 \\
\hline & $(8.54)$ & $(-35.84)$ & (18.19) & (1.14) \\
\hline \multirow{2}{*}{ Inventory } & $0.0958^{* * *}$ & $0.109^{* * *}$ & $0.0910^{* * *}$ & $0.0800^{* *}$ \\
\hline & $(23.11)$ & $(21.76)$ & (29.78) & (2.35) \\
\hline \multirow{2}{*}{ Grossmargin } & $-0.000513^{* * *}$ & $-0.000180^{* * *}$ & $-0.000457^{* * *}$ & $-0.000548^{*}$ \\
\hline & $(-15.79)$ & $(-5.80)$ & $(-17.57)$ & $(-1.71)$ \\
\hline \multirow{2}{*}{ FS } & $-0.000575^{* * *}$ & $-0.000167^{* * *}$ & $-0.000651^{* * *}$ & -0.000397 \\
\hline & $(-15.32)$ & $(-4.39)$ & $(-21.79)$ & $(-1.26)$ \\
\hline \multirow{2}{*}{ Intangible } & $0.0945^{* * *}$ & $0.128^{* * *}$ & $0.0642^{* * *}$ & 0.0843 \\
\hline & $(10.09)$ & (11.99) & $(8.75)$ & $(0.9)$ \\
\hline Observations & \multicolumn{2}{|l|}{8579} & \multicolumn{2}{|l|}{2417} \\
\hline
\end{tabular}

${ }^{*} \mathrm{p}<0.1, \quad * * \mathrm{p}<0.05, \quad * * \mathrm{p}<0.01$

Note: T-Value in parentheses.

Table 4: Regression Analysis of Main Variables of Model (1) \& Model (2)

\begin{tabular}{|c|c|c|c|c|c|c|c|c|c|}
\hline \multirow{2}{*}{ Variable } & \multicolumn{2}{|c|}{ Overcon1 } & \multicolumn{2}{|c|}{ Overcon2 } & \multirow{2}{*}{ Variable } & \multicolumn{2}{|c|}{ Overcon1 } & \multicolumn{2}{|c|}{ Overcon2 } \\
\hline & Coefficients & T-Value & Coefficients & T-Value & & Coefficients & T-Value & Coefficients & T-Value \\
\hline Model & \multicolumn{4}{|c|}{ Model (1) } & Model & \multicolumn{4}{|c|}{ Model（2) } \\
\hline \multirow{2}{*}{ Overcon1 } & \multirow{2}{*}{$0.153^{* * *}$} & \multirow{2}{*}{13.44} & & & Overcon1 & $0.161^{* * *}$ & 17.54 & & \\
\hline & & & & & Overcon2 & & & $0.886^{* * *}$ & 7.41 \\
\hline Overcon2 & & & $0.0127^{* * *}$ & 5.53 & Overcon $1 *$ ICI & $-0.0149 * * *$ & -5.7 & & \\
\hline Size & $0.00333^{* * *}$ & 8.26 & $0.00176^{* * *}$ & 4.97 & Overcon $2 *$ ICI & & & $-0.133^{* * *}$ & -7.21 \\
\hline \multirow{2}{*}{ Controller } & \multirow{2}{*}{$0.0289^{* * *}$} & \multirow{2}{*}{31.53} & \multirow{2}{*}{$0.0236^{* * *}$} & \multirow{2}{*}{22.78} & ICI & $-0.0740^{* * *}$ & -16.6 & $-0.0295^{* * *}$ & -9.67 \\
\hline & & & & & Size & 0.000124 & 0.27 & $0.00283^{* * *}$ & 8.58 \\
\hline LEV & $0.0912^{* * *}$ & 39.16 & $0.0576^{* * *}$ & 24.3 & Controller & $0.128^{* * *}$ & 7.54 & $0.0288^{* * *}$ & 37.41 \\
\hline ROA & $0.00256^{* * *}$ & 22.34 & $0.00322^{* * *}$ & 32.21 & LEV & $0.0883^{* * *}$ & 43.12 & $0.0676^{* * *}$ & 41.73 \\
\hline Inventory & $0.0966^{* * *}$ & 34.16 & $0.0936^{* * *}$ & 31.62 & ROA & $0.00416^{* * *}$ & 40.15 & $0.00333^{* * *}$ & 29.63 \\
\hline Grossmargin & $-0.000204^{* * *}$ & -8.31 & $-0.000165^{* * *}$ & -7.64 & Inventory & $0.0811^{* * *}$ & 29.43 & $0.0916^{* * *}$ & 35.6 \\
\hline FS & $-0.000483^{* * *}$ & -18.72 & $-0.000261^{* * *}$ & -11.2 & Grossmargin & 0.00000974 & 0.44 & 0.00000149 & 0.07 \\
\hline Intangible & $0.0783^{* * *}$ & 11.58 & $0.0646^{* * *}$ & -0.52 & FS & $-0.000634^{* * *}$ & -24.01 & $-0.000497^{* * *}$ & -29.26 \\
\hline \multirow{2}{*}{ YEAR } & \multirow{2}{*}{\multicolumn{4}{|c|}{ control }} & Intangible & $0.0553^{* * *}$ & 7.15 & $0.0274^{* * *}$ & 4.78 \\
\hline & & & & & YEAR & \multicolumn{4}{|c|}{ control } \\
\hline INDUSTRY & \multicolumn{4}{|c|}{ control } & INDUSTRY & \multicolumn{4}{|c|}{ control } \\
\hline Observations & \multicolumn{2}{|c|}{8579} & \multicolumn{2}{|c|}{3307} & Observations & \multicolumn{2}{|l|}{6294} & \multicolumn{2}{|l|}{2417} \\
\hline
\end{tabular}




\section{CONCLUSION}

The results of This paper show that there is a positive correlation between managers' overconfidence and the actual tax burden of enterprises. The higher the quality of internal control, the weaker the positive relationship. It enriches the existing research of the personal characteristics of the managers influence on the value of the company, and also expanded the research on the factors affecting the actual tax burden of enterprises.

First, managers are not "completely rational", and the cognitive bias caused by their personal personality traits will affect the decision-making process of the company and even hurt the company's value. Enterprises should pay more attention to such awareness bias, establish a sound corporate decision-making system to avoid the negative impact of such irrational factors on corporate value. Second, companies can proactively identify overconfident managers, some companies seeking innovation may prefer these kind of managers.

However, attention should be paid to the positive impact of overconfidence managers on the actual tax burden of enterprises, internal control should be improved to make up for the loss of corporate value caused by excessive self-confidence of managers. Third, in the context of agency issues, corporate managers are motivated to pursue their own private interests, while shareholder and other corporate equity holders prefer executives to act more as agents for their interests. This study finds that due to the overconfidence personality traits, even if managers hold the belief of maximizing the value of the company, they may still behave in ways that harm the value of the company. How to mitigate this kind of corporate governance deviation caused by personal characteristics of managers will be a worthwhile research direction.

\section{REFERENCES}

[1] Weinstein, N.D. 1980. Unrealistic optimism about future life events. Jo urnal of Personality \& Social Psychology, 39 (5), 806-820.

[2] Malmendier, U., Tate, G. 2015. Behavioral ceos: the role of managerial overconfidence.Journal of Economic Perspectives, 29 (4), 37-60.

[3] Humphery-Jenner, M., Ling, L.L., Nanda, V., Silveri, S.D. 2014. Executive overconfidence and compensation structure. Journal of Financial Econom ics, 119 (3), 533-558.

[4] Langer, E.J. 1975. The illusion of control. Journal of Personality and So cial Psychology,32 (2), 311-328.

[5] Ehrlinger, J., Mitchum, A.L., Dweck, C.S. 2016. Understanding overconfi dence: theories of intelligence, preferential attention, and distorted self-a ssessment. Journal of ExperimentalSocial Psychology, 63, 94-100.

[6] Chen, G., Crossland, C., Luo, S. 2015. Making the same mistake all over again: ceo overconfidence and corporate resistance to corrective feedbac k. Social Science Electronic Publishing, 36 (10), 1513-1535.

[7] Hribar, P., Yang, H. 2016. Ceo overconfidence and management foreca sting. Contemporary Accounting Research, 33 (1), 204-227.

[8] Banerjee, S., Humpheryjenner, M., Nanda, V. 2015. Restraining overco nfident ceos through improved governance: evidence from the sarbanesoxley act. Review of Financial Studies, 28 (10), 2812-2858.

[9] Hambrick, D.C. 1997. Explaining the premiums paid for large acquisiti ons: evidence of ceo hubris. Administrative Science Quarterly, 42 (1), 103 $-127$.

[10] Porcano, T.M. 1986. Corporate tax rates: progressive, proportional, o $r$ regressive. Journal of the American Taxation Association, 7 (2), 17-31. 